\title{
ПРОФЕССИОНАЛЬНАЯ ДЕФОРМАЦИЯ ЛИЧНОСТИ В ЮРИДИЧЕСКОЙ ДЕЯТЕЛЬНОСТИ
}

\section{PROFESSIONAL DEFORMITY AND ITS FEATURES IN LEGAL ACTIVITY}

\section{Melnikov}

Summary: The article deals with the essence and specific features of professional deformation in legal activity. The main types, dominant factors, as well as the connection of professional deformation with identical phenomena, such as professional destruction, the syndrome of «emotional burnout», are distinguished. Emphasizes the danger of the risk of exposure to the criminal environment for young lawyers. The author points out the need for early diagnosis of professional deformity of legal personnel. The author points out the need for early diagnosis of professional deformity of legal personnel, and suggests creating a model for psychological monitoring of deformity, professional destructions, emotional burnout, and other negative phenomena.

Keywords: legal activity, personality professional deformation professional destruction, burnout syndrome, diagnosis and psychological monitoring of deformation, professional destruction.
И сследователей давно привлекают внимание общие и специальные проблемы влияния профессии на человека, прошедшего специальное обучение и подготовку.

Среди многих профессий люди часто выбирают и стремятся получить специальность юриста. Труд юриста направлен на устранение проблем в обществе, правотворчество и реализацию норм права, поэтому юридическую деятельность характеризует чрезвычайно высокий уровень социальной ответственности. В действующей редакции от 14.03.2020 Конституции Российской Федерации отмечается юридическая профессия.

Профессиональная позиция и деятельность юриста продолжают быть образцом. В условиях построения демократического правового государства, социономический характер деятельности предъявляет юристам высокие профессиональные, морально-этические и нравственные требования. Профессиональное поведение юристов подкрепляется морально-этическими нормами.

Однако, эта профессии обладает собственным набором трудностей и оказывает сильное влияние на поведение и действия ее представителей. В процессе социально-психологических взаимодействий юриста сопровождает риск ответственности, напряжение, опас-
Мельников Владимир Михайлович

К.nсх.н., дочент, Бурятский государственный университет, г. Улан-Удэ melnikov-baikal@yandex.ru

Аннотация: В статье рассматривается сущность и специфические особенности профессиональной деформации в юридической деятельности. Выделяются основные виды, доминирующие факторы, а также связь профессиональной деформации с идентичными явлениями, как профессиональная деструкция, синдром «эмоционального выгорания». Подчеркивает опасность риска воздействия криминогенной среды на молодых юристов. Указывается на необходимость ранней диагностики профессиональной деформации юридических кадров, предлагается создать модель психологического мониторинга деформации, профессиональных деструкций, эмоционального выгорания и иных негативных явлений.

Ключевые слова: юридическая деятельность, личность профессиональная деформация, профессиональная деструкция, синдром эмоционального выгорания, диагностика и психологический мониторинг деформации, профессиональных деструкций.

ность для жизни и здоровья.

Именно поэтому в науке среди многих тем проблема профессионального труда, занимает особое место и положение то нашло отражение в исследованиях А.К. Маркова, С.Г. Геллерштейн и Э.Ф. Зеер, Г. Селье, П. Мучински.

Изучение указанной проблемы не сводится к узкопознавательной теме, как правило, во главу угла берутся разные темы, идеи личного и социального с позитивной установкой на формирование личности юриста. На этом фоне в профессии юриста особый интерес представляет социальный феномен профессиональной деформации. На этом фоне среди современных отечественный ученых выделяются труды А.Р. Ратинова (1967); Л.С. Свецицкого (1986); Г.Г. Шиханцова (1998); Н.Л. Гранат (1993); А.В.Буданова (1992,1994); С.П. Безсонова (1987.1997, 2004); С.Е. Борисова (1998, 2001); В.С. Медведева (1999); Р.А. Кузнецова (2005); В.В. Шпунтова (2008); В.С. Бреднева (2019) и др.

Ученые до настоящего времени спорят и предлагают различные трактовки профессиональной деформации. По мнению Е.И. Рогова профессиональная деформация появляется под влиянием выполняемой деятельности и жестких ролевых стереотипов, которые переносятся из трудовой сферы в иные условия, когда человек не способен перестраивать свое поведение адекватно меняю- 
щимся условиям [1].

В нашем понимании профессиональная деформация это особое внутреннее состояние отступления личности от главных личностных качеств, которая обнаруживает зону внутреннего конфликта на уровне стереотипов и разбалансированности восприятия, категорий ценности, характера, способов коммуникации и поведения. В одних случаях она приводит к развитию профессионально нежелательных качеств, в иных, к серьезным ошибкам и профессиональной дезадаптации.

В научной и профессиональной среде можно встретить понятие профессиональной деформации правосознания и профессиональной деструкции. С позиции С.П. Безносова профессиональная деформация как явление характеризуется негативно, как нечто противоестественное и вызванное объективными факторами воздействием длительного выполнения собственной профессиональной деятельности [2].

Профессиональная деструкция также имеет свои особенности, это нарушение усвоенных способов деятельности, низкая мобильной и дезинтеграция развития, постепенное разрушение профессиональных качеств, появление «жестких» стереотипов профессионального поведения, вплоть до распада профессионального сознания. Специалисты утверждают, что чаще всего это связано с возрастными и социальными нормами жизни человека.

В зарубежных научных источниках вместо понятия «профессиональная деформация» используется термин «эмоциональное выгорание», который содержит значительную по объему и уровню описания информацию о шести фазовом процессе выгорания, кризисе, редукции профессиональных достижений, стереотипах профессионального поведения др. Данное понятие включено в Международную классификацию болезней МКБ-10.

К настоящему времени в научной литературе накоплено достаточно интересных, взаимодополняющих наблюдений, фактов, сделано много теоретических выводов о феномене деформации.

Профессиональная деформация, появляется под влиянием выполняемой деятельности жестких ролевых стереотипов, которые переносятся из трудовой сферы в иные условия, когда человек не способен перестраивать свое поведение адекватно меняющимся условиям. Дополняет картину стагнация профессиональных возможностей, длительность воздействия отрицательных стрессоров, внутриличностный конфликт и др.

По мнению Е.Л. Карташовой профессиональная деформация приводит к изменениям профессиональных характеристик и возможностей личности в асоциальную сторону [3]. В результате страдает профессиональнонравственная сфера личности, нивелируются представления о гражданском и нравственном смысле профессиональной деятельности, что приводит к подмене норм в поведении и нарушению законности.

Оценивая влияние стресса в условиях труда, М. Борневассер делает вывод, что воздействие профессии может обнаруживаться на позитивном и негативном уровне модальности [4]. М.А. Воробьева рассматривая проблему динамики профессиональной деформации отмечает, что система личностных качеств формируются в результате длительного принятия определенной профессиональной роли [5]. Интересен вывод Н.В. Самоукиной о том, данное явление объединяет группу психофизических, социально-психологических и поведенческих симптомов [6].

О.Б. Полякова считает, что с психологической точки зрения наиболее сложная картина симптомов деформирует моральное сознание личности и руководителя [7].

Классификации основных видов профессиональной деформации пока нет, однако в некоторых работах можно встретить описание четырех групп разновидной этого явления:

- правовой инфантилизм, негативно-правовой радикализм, спекулятивно-правовой популизм, нравственно-правовой конформизм;

- общепрофессиональная, специальная, профессиональная, профессионально-типологическая, индивидуализированная;

- собственно-профессиональная, служебная (должностная), депривационная;

- случайная, эпизодическая, временная или устойчивая, поверхностная или всеобщая

В своем большинстве люди не испытывают сильного давления внешних и внутренних факторов профессиональной деятельности и оно не приводит к когнитивным искажениям и психологической дезориентации. Как и в других профессиях, в юридическом труде сложно вычислить нарастание или убывание профессиональной деформации и эмоционального выгорания. Это явление всецело зависит от специфики работы, суммы поведенческих контактов, психофизиологических особенностей личности, ее психологической устойчивости и многих других факторов.

Вместе с тем, профессиональной деформации могут быть подвержены молодые люди, делающие первые шаги в карьере юристы. Неблагоприятное протекание профессионального развития должно диагностироваться на этапе ранней профессионализации, особенно в условиях практико-ориентированного учебного моделирования профессионально-психологических трудностей на занятиях. 
В условиях слабой организации индивидуально-воспитательной работы и психолого-педагогического сопровождения, под воздействием косвенного, либо скрытого влияния деморализованной криминогенной среды риск зачаточного возникновения и развития профессиональных деструкций и профессиональной деформации возрастает. Если меры профилактического воздействия не принимаются, то в последующем деформация способна продолжить свою «работу» над сознанием личности. Как правило, на этом этапе деформация вызывает сильные противоречия, подменяется неосознанной потребностью снимать внутреннее напряжение, выплескивать накопленную агрессию на объекты воздействия.

Депривационная деформация также представляет опасность и связана с асоциальной перцепцией. На этом этапе нивелируются основные ценности и значение юридического труда, формируются корыстные потребности от использования своего положения и тех возможностей, которые ему даёт работа. Чаще всего, это обман, злоупотребление доверием. Не исключаются случаи предательства интересов службы.

В целом, с психологической точки зрения на фоне когнитивной блокировки и вытеснения (отрицания деформации) психические функции снижаются до глубинного уровня, затрагивая разные структуры личности.

В научной литературе представлена общая картина факторов, влияющих на развитие профессиональной деформации. Существенно то, что многие авторы довольно подробно описывают причинный комплекс деформации. Проведенный нами анализ позволил собрать в различном сочетании и суммировать наиболее весомые причины деформации. Существенно то, что в группу причин вошла мотивационая сфера (мотивация избегания неуспеха), наличие фрустрированности на внутрен- них проблемах; явно не высокий уровень самооценки; коммуникативная незрелость; неумение оценивать эмоциональные реакции собеседника и др.

Мы предполагаем, что полученные нами результаты оказались характерными для сравнительно небольшой группы обучающихся (будущих юристов) у которых, в силу возраста проблемно выглядит конгруэнтность, не сформирован поведенческий и мыслительный паттерн, эмоционально-личностные характеристики, стрессоустойчивость и др.

Обобщая сказанное можно сделать несколько выводов. Современные исследователи едины во взглядах на сложную реальность юридической деятельности, воздействие явно избыточных негативных факторов, «стереотипностью» [8] выполняемых задач, которые определяют индивидуальный тип поведения, сумму переживаний, дезадаптируют личность и запускают негативные процессы деформации.

Интеграция науки создает условия для всестороннего анализа стилевых поведенческих признаков, «индикаторов» формирующих полярные человеческие проявления. Однако, существует необходимость дальнейшего изучения феномена «эмоционально выгорания» юристов разных специальностей, для чего потребуется создание новых диагностических и психокоррекционных методик.

Качественная оценка современных научных достижений послужит хорошей предпосылкой для проведения новых исследований по разработке модели психологического мониторинга деформации, профессиональных деструкций, эмоционального выгорания и иных негативных явлений в будущих вызовах профессиональной деятельности юристов.

\section{ЛИТЕРАТУРА}

1. Рогов Е.И. Личностно-профессиональное развитие в профессиональной деятельности: автореф. дисс. ... докт. пед. наук. Ростов-на-Дону, 1999. С. 12.

2. Безносов С.П. Профессиональная деформация личности: подходы, концепции, метод: дис.... докт. псих. наук. СПбТУ, 2017. С. 68.

3. Карташова, Л. Е. Особенности профессионального правосознания юриста и пути его повышения / Л. Е. Карташова // Философские и социально-экономические аспекты формирования правового сознания граждан: материалы научно-практической конференции; отв. ред. И. И. Грунтовский. - 2016. C. 179-186.

4. Борневассер М. Стресс в условиях труда // Психические состояния. Хрестоматия. СПб.: Питер, 2014. С. 197.

5. Воробьева М.А. Профессиональная деформация специалистов и её профилактика // Педагогическое образование в России. 2015. № 2. С. 24.

6. Самоукина Н.В. Синдром профессионального выгорания // Медицинская газета. 2015. № 43. С. 21.

7. Полякова 0.Б. Особенности психосоматической симптоматики студентов-психологов с предпосылками профессиональных деформаций // Электронный научно-образовательный вестник «Здоровье и образование в XXI веке». 2016. № 11. С. 128.

8. Грановская Р. М. Элементы практической психологии / Р. М. Грановская. - Л.: ЛГу, 1984. 